\title{
PERUBAHAN PERILAKU EKONOMI MASYARAKAT SEBAGAI DAMPAK PENGEMBANGAN PARIWISATA ALAM PERDESAAN : STUDI KASUS PEMANDU WISATA AIR TERJUN NYARAI KECAMATAN LUBUK ALUNG, PROVINSI SUMATERA BARAT
}

\author{
Yudha Rahman ${ }^{1}$, Prihadi Nugroho² \\ ${ }^{1}$ Program Studi Magister Pembangunan Wilayah dan Kota, Fakultas Teknik Universitas Diponegoro \\ Semarang \\ ${ }^{2}$ Jurusan Perencanaan Wilayah dan Kota, Fakultas Teknik Universitas Diponegoro Semarang
}

\begin{abstract}
Special interest tourism is a new alternative for tourist in order to experience unique tourist attraction based on particular motivation and interest of the specific travelers. The local community of Gamaran Korong Salibutan has been heavily relying on forest resources to fulfill their daily need by cutting the trees in Gamaran protected the forest resulting in constant forest degradation. Whereas, the Gamaran Forest has huge potential to be a natural tourist destination. The study aims to understand the economical behavioral changes as an effect of the natural tourism development. The method used in this study is qualitative research with case study approach of Nyarai Waterfall attraction. The results show that the presence of tourism development of Nyarai Waterfall has positive benefits for the economy of the local community, in which there is an increase of income and job opportunities as a tour guide for those who initially worked as woodcutters or even the unemployed youths. In addition, the housewife is able to open a stall so that are able to add an extra for family income.
\end{abstract}

Keywords: Protected Forest, Special Interest Tourism, Community Empowerment, Community Based Tourism, Bottom Up Planning

\section{Pendahuluan}

\section{Latar Belakang}

Pariwisata merupakan sebuah fenomena dan keterkaitan yang muncul karena interaksi wisatawan, bisnis penyedia jasa, pemerintah dan komunitas setempat, dalam proses mendatangkan wisatawan atau pengunjung [9]. Aktivitas pariwisata merupakan salah satu sektor pembangunan yang memberikan efek nilai manfaat kepada banyak pihak dari pemerintah, masyarakat, ataupun swasta. Dalam Pariwisata, ada istilah Community Bassed Tourism (CBT) yang merupakan salah satu pendekatan dari bawah (bottom up) berupa kebijakan menunjukkan tantangan dan peluang bagi masyarakat tujuan untuk bekerja dengan sektor publik dan swasta [8].

CBT memiliki hubungan dengan Pengembangan Ekonomi Lokal (PEL) yang melibatkan partisipasi pemangku kepentingan Pariwisata. Hal ini terlihat dari peran masyarakat sebagai salah satu pemangku kepentingan dengan menggali potensi lokal. PEL merupakan proses ketika pemerintah lokal dan organsisasi masyarakat terlibat untuk mendorong, merangsang, memelihara, aktivitas usaha untuk menciptakan lapangan pekerjaan.

Masyarakat Korong Salibutan Nagari Lubuk Alung adalah masyarakat yang berada pada perbukitan Hutan Lindung Pemerintah Provinsi Sumatera Barat. Masyarakat hidup dengan mengandalkan hasil hutan dengan melakukan penebangan liar yang jika terus berlanjut akan menyebabkan berkurangnya jumlah hutan lindung sebagai kesatuan Bukit barisan Provinsi Sumatera Barat. Pengaruh penebangan yang liar yang dilakukakan oleh masyarakat yaitu berupa menurunnya kualitas lingkungan kondisi hutan dengan status Hutan Lindung. Namun masyarakat Desa Salibutan tidak ada alternatif pilihan lain selain menggantungkan hidup dengan eksplorasi hutan dengan melakukan penebangan pohon dalam hutan. Penebangan yang dilakukan adalah penebangan liar atau illegal.

Dalam Hutan Lindung Korong Salibutan, pada tiga tahun terakhir telah ditemukan sebuah air Terjun yang indah yang dinamai Air Terjun Nyarai. Air Terjun Nyarai merupakan objek wisata alam yang baru yang merupakan salah satu air terjun terindah yang ditemukan di Sumatera Barat. Air Terjun ini terletak di Hutan Gamaran, Kecamatan Lubuk Alung, Kabupaten Padang Pariaman, Sumatera Barat. 
Dengan adanya Air Terjun Nyarai ini menjadi potensi wisata untuk dikembangakan sebagai Desa Wisata dengan Pariwisata Minat Khusus yang melibatkan masyarakat. Wisata Air Terjun Nyarai dapat dikembangkan menjadi Pariwisata Minat Khusus yang melibatkan pemberdayaan masyarakat lokal, pemerintah daerah, serta organisasai masyarakat sehingga segala potensi wisata Air Terjun Nyarai bisa menjadi alternatif pengembangan Desa Wisata yang memberi kontribusi terhadap ekonomi masyarakat sehingga perlahan masyarakat lokal mulai meninggalkan aktivitas penebangan hutan.

\section{Gambaran Umum Lokasi Air Terjun Nyarai Di Korong Salibutan}

Air Terjun Nyarai berada pada Hutan Gamaran Korong Salibutan, Nagari Lubuk Alung, Kecamatan Lubuk Alung. Kawasan Wisata Air Terjun Nyarai adalah bagian arus Sungai Lubuak Nyarai yang terus mengalir dari dalam Hutan Gamaran sampai Sungai Batang Salibutan yang mengaliri sepanjang Korong Salibutan sampai bertemu Sungai Batang Anai dan bertemu dengan muara.

Kawasan Wisata Air Terjun Nyarai sebagai bagian dari Sungai Lubuak Nyarai terletak di dalam Hutan Gamarang dan berada pada bagian Timur Korong Salibutan Nagari Lubuk Alung, Kecamatan Lubuk Alung.

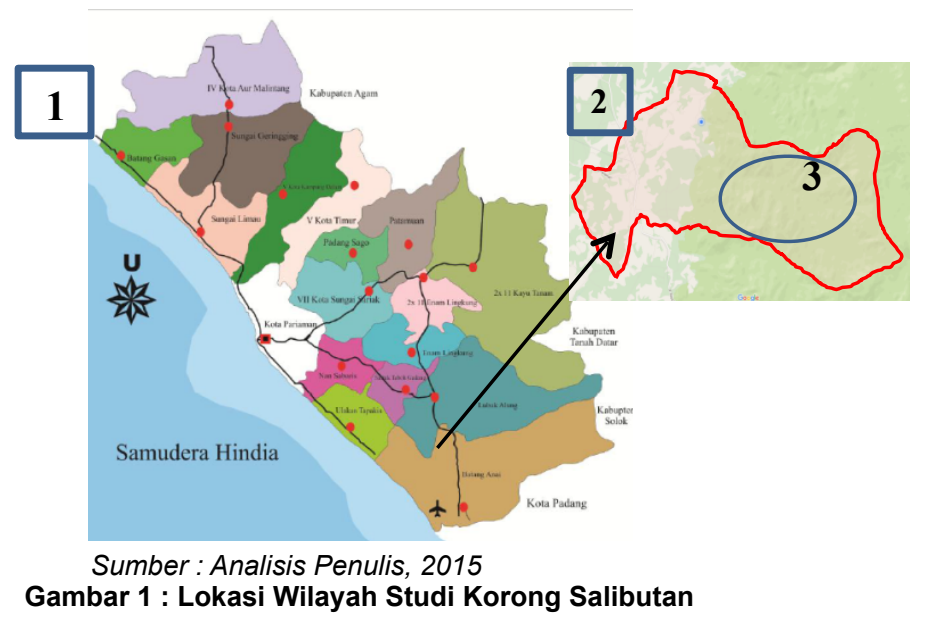

Keterangan Gambar

1. Kabupaten Padang Pariaman

2. Kecamatan Lubuk Alung

3. Lokasi Korong Salibutan lokasi Air Terjun Nyarai

\section{Kajian Teori Pengaruh Pariwisata Terhadap Ekonomi Dan Pemberdayaan Masyarakat}

\subsubsection{Pengertian Pariwisata dan Pariwisata Minat Khusus}

Secara etimologi, kata pariwisata berasal dari bahasa Sansekerta yang terdiri dari dua suku kata, yaitu pari dan wisata. "Pari berarti banyak, berputar-putar dan lingkup, sedangkan wisata adalah perjalanan. Pariwisata adalah Suatu proses bepergian seseorang atau lebih menuju tempat lain di luar tempat tinggalnya [6]. Menurut Undang Undang No. 10 tahun 2009 tentang Kepariwisataan, yang dimaksud dengan pariwisata adalah berbagai macam kegiatan wisata yang didukung oleh berbagai fasilitas serta layanan yang disediakan masyarakat, pengusaha, pemerintah dan pemerintah daerah.

Dalam melakukan perjalanannya wisatawan bukan lagi bertujuan untuk melihat atau mengunjungi banyak daerah tujuan wisata dengan banyak keragaman atraksi, melainkan lebih menekankan pada kekayaaan pengalaman yang didapatkan melalui keterlibatannya dalam suatu kegiatan. Maka karena fenomena inilah lahirlah Pariwisata Minat Khusus. Wisata minat khusus adalah salah satu bentuk wisata alternatif yang merupakan suatu bentuk perjalanan wisata, dalam hal ini wisatawan melakukan perjalanan atau mengunjungi suatu tempat karena memiliki suatu minat atau motivasi khusus mengenai suatu jenis objek atau kegiatan yang dapat ditemui atau dilakukan di sebuah lokasi wisata [4]. Kategori Pariwisata yang tergolong dalam Pariwisata Minat Khusus adalah : Wisata petualangan, Pariwisata Perdesaan, Pariwisata budaya, Pariwisata Keagamaan, Ekowisata, Wisata kuliner, Pariwisata Kehidupan alam liar, Pariwisata Sejarah, dan Wisata Medis. 


\subsubsection{Perubahan Perilaku Ekonomi berupa Pengaruh Pariwisata terhadap Ekonomi}

Pengembangan Pariwisata sangat penting dalam isu pengembangan ekonomi dalam suatu wilayah [2]. Pariwisata bisa menjadi sumber ekonomi pada suatu wilayah. Pariwisata bisa menjadi solusi dalam pengembangan ekonomi lokal dan saling melengkapi dalam aktivitas ekonomi suatu wilayah. Pariwisata Modern adalah kunci penggerak untuk pembangunan sosial ekonomi seperti dampak terhadap lapangan pekerjaan, investasi lokal, serta pembangunan infrastruktur. Menurut [6] Pariwisata memberi kontribusi kepada penciptaan lapangan pekerjaan, perbaikan infrastruktur dan membantu perkembangan infrastruktur wilayah.

\subsubsection{Pengaruh Pariwisata Terhadap Pemberdayaan Masyarakat}

Dalam pengaruh pariwisata terhadap masyarakat lokal adalah proses pemberdayaan masyarakat dalam mengelola pariwisata. Kehadiran Pariwisata hendaknya mampu mendorong masyarakat untuk berpartisipasi secara aktif dalam rangka mencapai tujuan kesejahteraan dan pemberdayaan masyarakat lokal. Pemberdayaan masyarakat adalah sebuah proses dan tujuan [7]. Pariwisata Berbasis Masyarakat/ Community Based Tourism (CBT) adalah pariwisata yang menyadari kelangsungan budaya, sosial, dan lingkungan. Bentuk pariwisata ini dikelola dan dimiliki masyarakat untuk masyarakat, guna membantu para wisatawan untuk meningkatkan kesadaran mereka dan belajar tentang masyarakat dan tata cara hidup masyarakat lokal (local way of life). Maka dari pengertian ini sangat jelas bahwa CBT berbeda dengan pariwisata massa (mass tourism).

Dalam CBT peran masyarakat sangat identik dengan partisipasi masyarakat. Pada proses partisipasi terdapat tangga partisipasi yang terbagi menjadi tiga tahap yang dikenal dengan $A$ Ladder of Citizen Participation menurut [5], yakni Non participation, Tokenisme, dan Degree of Cityzen Power. [5] menyatakan bahwa partisipasi masyarakat identik dengan kekuasaan masyarakat (citizen partisipation is citizen power). Partisipasi masyarakat bertingkat sesuai dengan gradasi kekuasaan yang dapat dilihat dalam proses pengambilan keputusan

\section{Metode Penelitian}

Penelitian ini dilakukan dengan metode penelitian kualitatif dengan pendekatan studi kasus karena menggali perubahan perilaku ekonomi masyarakat sebagai dampak pengembangan pariwisata alam perdesaan dengan studi kasus pemandu wisata Air Terjun Nyarai. Melalui pendekatan studi kasus peneliti berupaya untuk mengatahui apa saja perubahan perilaku masyarakat karena dampak perkembangan pariwisata Air Terjun Nyarai. Dalam penelitian digunakan teknik sampling yakni purposive sampling. Jumlah informan yang didapatkan selama kegiatan pengumpulan data yang mewakili empat pemangku kepentingan yang terlibat dalam pariwisata Nyarai yaitu Kelompok Sadar Wisata LA Adventure, Pemerintah Daerah Kabupaten Padang Pariaman, masyarakat lokal Gamaran Korong Salibutan, dan wisatawan sebanyak 15 orang Informan wawanacara selama penelitian.

Selain itu juga ada tambahan data untuk penunjang analisis perubahan pendapatan masyarakat dalam bentuk presentase dan statistik kuantitatif berupa 62 kuesioner masyarakat yang mewakili 165 masyarakat lokal yang terlibat menjadi pemandu wisata. Metode pengumpulan data dilakukan dengan metode pengumpulan data primer, berupa wawancara kepada pemangku kepentingan terkait pariwisata Air Terjun Nyarai, observasi lapangan berupa dokumentasi foto dan pengumpulan data sekunder dengan menggunakan telaah dokumen yang mendukung penelitian.

Analisis dilakukan dengan menggunakan teknik analisis deskriptif kualitatif. Analisis dimulai dengan memberikan deskripsi tentang Karakteristik Wisata Air Terjun Nyarai dan karakteristik dan kegiatan masyarakat Korong Salibutan serta permasalahan yang terjadi sebelum dan pasca pengembangan wisata Air Terjun Nyarai. Setelah itu dilakukan analisis deskripsi berupa perubahan perilaku ekonomi masyarakat terkait pengembangan pariwisata Nyarai. Perubahan perilaku ini akan menuntut terjadinya pemberdayaan masyarakat. Dari analisis perubahan perilaku ekonomi dan pemberdayaan masyarakat dikaitkan dengan Pengembangan Ekonomi Lokal dan perananan pemangku kepentingan pariwisata. Dari setiap analisis memiliki kesimpulan dan temuan studi yang dirinci dalam setiap subbab analisis. 


\section{Pembahasan}

\section{Analisis Karakteristik Wisata Air Terjun Nyarai Korong Salibutan Nagari Lubuk Alung}

Area Hutan Gamaran memiliki kepemilikan yang berbeda, yaitu berada pada Hutan Area Penggunaan Lain (APL) dengan kepemilikan dari masyarakat dan Hutan Lindung (HL) dengan status kepemilikkan oleh Negara. Status Hutan Lindung sedang diproses untuk jadi Hutan Desa atau di Sumatera Barat disebut Hutan Nagari dengan pedoman Peraturan Menteri Kehutanan Republik Indonesia No 89 tahun 2014 tentang Hutan Desa. Jadi, dengan adanya status Hutan Desa atau di minangkabau disebut Hutan Nagari, pengelolaan dan pemanfaatan hutan diserahkan kepada masyarakat lokal. Masyarakat boleh mengembangkan pariwisata Air Terjun Nyarai dalam Hutan Gamaran dengan ketentuan tidak merusak alam.

Dalam Pariwisata Minat Khusus Air Terjun Nyarai aspek wisata minat khusus yang ditekankan adalah sensasi trekking yang dirasakan oleh wisatawan selama menempuh perjalanan dari posko menuju Air Terjun Nyarai. Pada saat trekking wisatawan sambil menikmati sensasi alami Hutan Gamaran yang masih banyak terdapat flora dan fauna endemik. Selain Trekking, yang menarik dari wisata minat khusus ini adalah peran pemandu. Pemandu adalah masyarakat lokal Gamaran. Daya Tarik alam yang potensial untuk dikembangkan adalah Wildlife Tourism. Wildlife merupakan kehidupan liar flora fauna endemik di Hutan Gamaran sangat potensial sebagai salah satu aspek wisata Minat Khusus yang menarik wisatawan yang memiliki jiwa petualangan.

Dengan adanya perkembangan Pariwisata Air Terjun Nyarai memberi dampak positif terhadap kawasan Korong Salibutan dengan bangkit kembali sanggar seni yang sudah lama pasif dan tidak ada kegiatan lagi. Sanggar seni yang ada di Korong Salibutan adalah Sanggar seni Sikapur Sirih yang memiliki kegiatan dengan melestarikan tradisi kebudayaan yaitu: Pencak Silat, Indang, Randai, dan Basaluang. Atraksi kebudayaan ini sampai saat ini pelaksanaan penampilan atraksi budaya nya belum terkelola dengan baik karena fokus Pokdarwis LA Adventure sendiri adalah Wisata Petualangan dalam Hutan Gamaran.

\section{Analisis Karakteristik dan kegiatan masyarakat Korong Salibutan serta permasalahan yang terjadi sebelum dan pasca Pengembangan Wisata Air Terjun Nyarai}

Masyarakat Gamaran Korong Salibutan adalah tipikal masyarakat pedesaan tradisional yang masih minim dengan teknologi dan dengan kualitas sumber daya manusia yang cukup rendah karena masyarakat banyak lulusan SD-SMP. Tingkat pendidikan dan pengetahuan yang rendah menyebabkan rendahnya kualitas sumber daya manusia sehingga banyaknya masyarakat usia produktif seperti pemuda dan pemudi yang menganggur. Modal sosial masyarakat Lokal Korong Salibutan saat ini masih terjaga dan berjalan dengan Baik. Kepercayaan antarsesama masih dijunjung oleh masyarakat diantaranya percaya kepada keputusan Niniak Mamak untuk memberi izin membuka wisata sebagai salah satu keputusan terbaik dan saling percaya antar sesama masyarakat. Norma Sosial masyarakat Korong Salibutan masih memegang teguh aturan norma sesuai adat minangkabau, dan terkait Jaringan kerja, masyarakat lokal sudah bisa membuka peluang dan kerjasama dengan berbagai pihak untuk kemajuan pengembangan wisata.

Pemasalahan dalam masyarakat yang terjadi saat sebelum dikembangkan adalah : pertentangan dari pemilik tanah, pola pikir masyarakat yang belum berkembang, dan tantangan dari luar seperti kecemburuan pihak lain seperti pihak komunitas pecinta alam lainnya. Seiring perkembangan Wisata Air Terjun Nyarai, beberapan masalah yang dan pertentangan yang ada mulai berkurang. Permasalahan lain adalah masih ada beberapa masalah yang terjadi pasca pengembangan Pariwisata Nyarai yaitu : masalah internal masyarakat, aktivitas penebangan yang belum berhenti sepenuhnya, dan aksesibilitas menuju Gamaran yang masih buruk. 


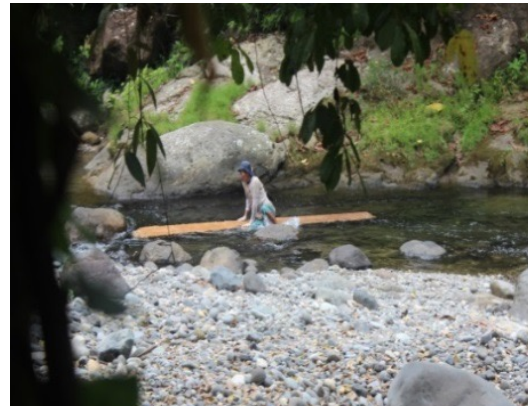

Sumber : Observasi Lapangan, 2015

(A)

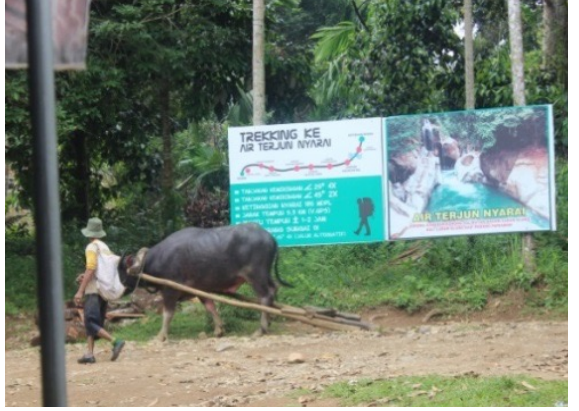

(B)

Gambar 2 : Aktivitas Penebangan Liar Yang Masih Berlangsung

(A) Aksi Penebang Kayu Dalam Hutan Gamaran

(B) Penebang Yang Baru Keluar Dari Hutan

Eksistensi Air Terjun Nyarai sebagai objek wisata alam minat khusus tidak lepas dari peran wisatawan. Jumlah Wisatawan ke Air Terjun Nyarai mengalami naik turun selama hampir tiga tahun berjalan. Semenjak awal dibuka untuk wisatawan masyarakat luar pada bulan April 2013, jumlah pengunjung naik dan meningkat sampai puncak pengunjung terbanyak pada bulan Maret 2014 yang mencapai 8342 wisatawan. Pengunjung menurun sampai angka 3000 an sampai bulan Agustus 2014, selanjutnya dari Bulan Agustus 2014 sampai tahun 2015 pengunjung stabil sekitar 1000 an pengunjung perbulannya. Wisatawan Trekking ke Air Terjun Nyarai adalah muda-mudi dari pelajar, mahasiswa, dan karyawan yang penasaran akan sensasi trekking dan melihat keindahan Air Terjun Nyarai secara langsung

\section{Analisis Perubahan Perilaku Ekonomi Masyarakat dengan Adanya Pengembangan Pariwisata Air Terjun Nyarai}

Aliran uang untuk pendapatan ekonomi masyarakat lokal bersumber dari uang kontribusi wisatawan yaitu Rp 20.000/ orang. Untuk setiap distribusi pembagian uang hasil wisata dibagi sedemikian rupa dengan anggota yang terlibat yaitu pendapatan bersih dibagi dengan presentasi $60 \%$ masuk dana khas serta kegiatan operasional wisata dan $40 \%$ untuk dana kepada pengurus yang bekerja dan terlibat pada shift tersebut. Untuk Pemandu Wisata Rp 80.000 sekali trekking dan pemandu Camping Rp 150.000 per malam

Dari kegiatan ekonomi masyarakat Korong Salibutan mengalami perubahan perilaku ekonomi karena sudah mulai beralih meninggalkan kegiatan menebang pohon di hutan dan terlibat untuk mendukung sektor wisata Nyarai. Keterlibatan masyarakat beragam seperti menjadi pemandu wisata Nyarai, sektor penyedia kebutuhan penunjang wisata seperti penyewaan pelampung, warung makan, dan souvenir. Dalam aktivitas ekonomi masyarakat yang mendukung keberlangsungan pariwisata Nyarai telah terjadi beberapa kenaikan pendapatan masyarakat. Keterlibatan dan peran masyarakat yang berbeda-beda membuat tingkat kenaikan dan pendapatan yang juga berbeda. Berikut hasil presentase pendapatan menjadi pemandu wisata Nyarai dalam menjalankan perannya dan manfaat yang dirasakan secara ekonomi, berupa pengukuran besar penghasilan pemandu wisata Air Terjun Nyarai dari sebelum menjadi pemandu, pengahasilan menjadi pemandu, penghasilan setelah tambahan menjadi pemandu, serta presentase ada tidaknya perubahan pendapatan responden dapat dilihat pada diagram berikut : 


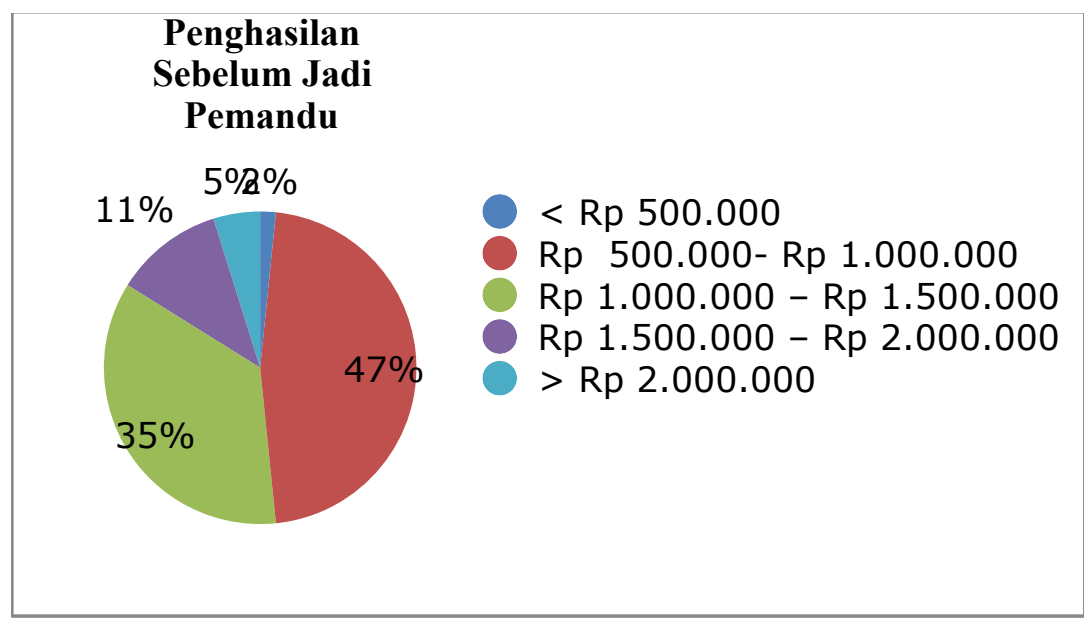

(A)

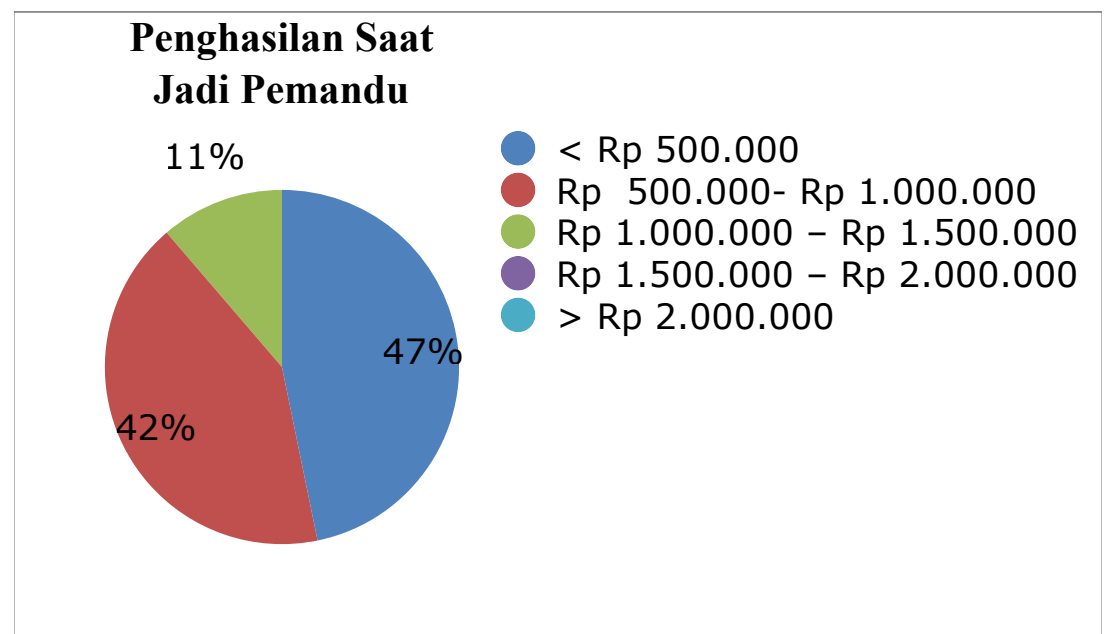

(B) 


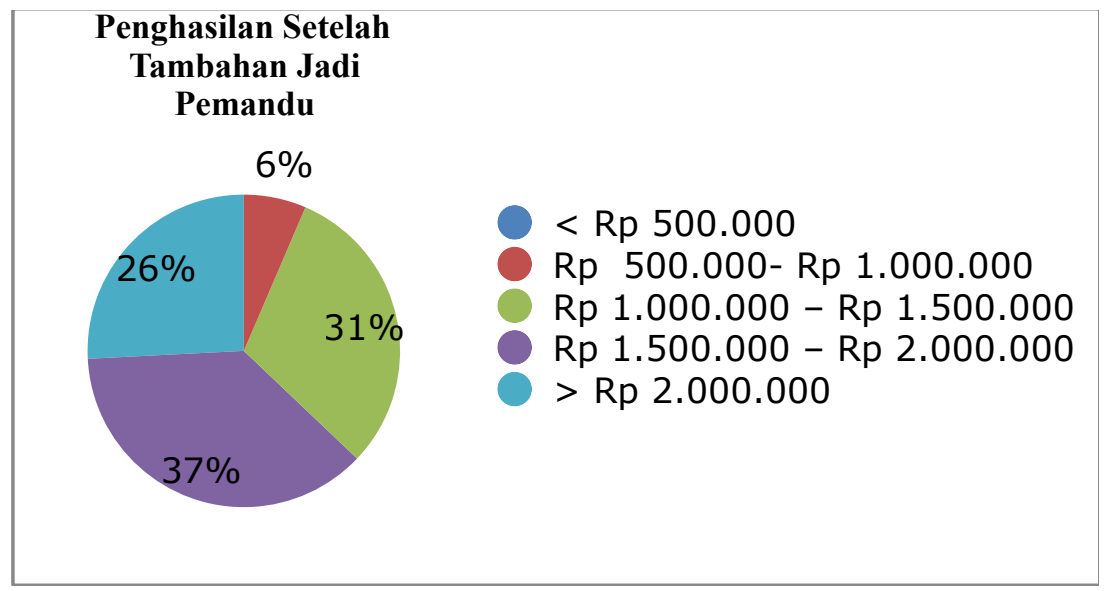

(C)

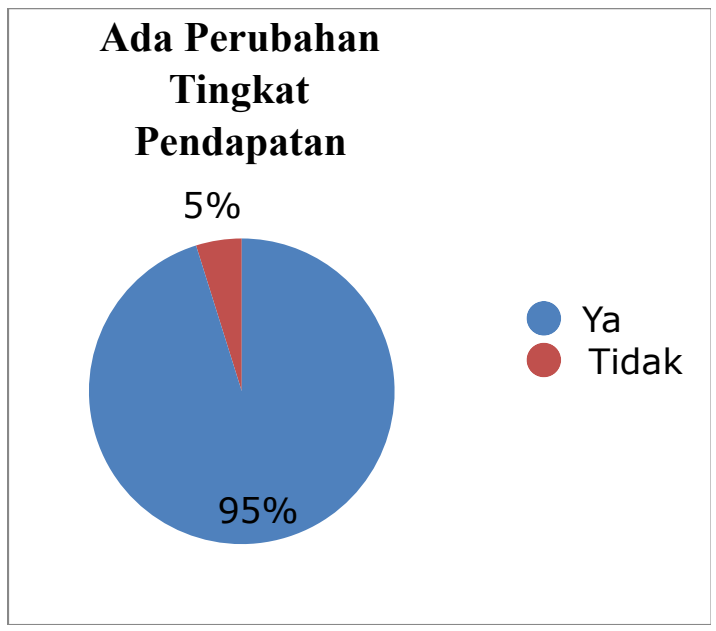

(D)

Sumber : Analisis Penulis, 2016

Gambar 3 : Prosentasi Penghasilan Masyarakat Pemandu Wisata dan Prosentasi Perubahan Pendapatan
(A) Tingkat Penghasilan Masyarakat Sebelum Menjadi Pemandu Wisata
(B) Tingkat Penghasilan Masyarakat Menjadi Pemandu Wisata
(C) Tingkat Penghasilan Masyarakat Ditambah Penghasilan Menjadi Pemandu Wisata
(D) Prosentase Ada/Tidak Perubahan Pendapatan Pemandu Nyarai

Dari grafik diatas untuk Gambar 3A tingkat penghasilan Responden masyarakat sebelum menjadi pemandu, penghasilan masyarakat paling banyak adalah kisaran Rp 500.000 - Rp 1.000.000 dengan prosentase 47\%, urutan kedua kisaran Rp 1.000 .000 - Rp 1.500 .000 sebesar 35\%, urutan ketiga pendapatan Rp 1.500.000 - Rp 2.000.000 sebesar 11\%, penghasilan lebih dari Rp 2.000 .000 sebesar $5 \%$, dan penghasilan sangat kecil dibawah $\mathrm{Rp} 500.000$ sebesar $2 \%$. Penghasilan masyarakat sebelum menjadi pemandu yang terbesar adalah berada pada skala Rp 500.000-Rp 1.000.000 dan $\mathrm{Rp}$ 1.000.000-Rp 1.500.000. Penghasilan ini adalah dari pekerjaan utama masyarakat berupa wiraswasta (pedagang), petani dan buruh, serta lain-lain (pengangguran dan serabutan). Penghasilan terbesar adalah masyarakat yang menjadi pedagang warung di Korong Salibutan dan pedagang di Pasar Lubuk Alung, serta penghasilan skala Rp 500.000 - Rp 1.000.000 per bulan didominasi 
masyarakat yang menjadi petani dan buruh (buruh ternak ayam dan buruh pembuatan batu bata). Dari diagram tersebut kita bisa mengetahui bahwa penghasilan masyarakat lokal sangat beragam dari yang sangat kecil dibawah Rp 500.000 hingga ada juga yang lebih besar dari Rp 2.000.000. Hal ini mengindikasikan bahwa masyarakat lokal Gamaran Korong Salibutan yang menjadi pemandu ternyata tersebar tidak hanya masyarakat yang memiliki penghasilan rendah, tetapi juga masyarakat yang memiliki penghasilan sedang. Kebutuhan hidup masyarakat yang beda-beda membuat masyarakat tetap tertarik untuk terlibat sebagai pemandu wisata walau penghasilan dari pekerjaan utama sudah cukup pada skala masyarakat perdesaan.

Untuk Gambar 3B tingkat penghasilan Responden masyarakat ketika menjadi pemandu, penghasilan menjadi pemandu wisata yang paling banyak adalah kisaran di bawah Rp 500.000 dengan prosentase 47\%, urutan kedua kisaran Rp 500.000 - Rp 1.000 .000 sebesar $42 \%$, urutan ketiga pendapatan $\mathrm{Rp}$ 1.000 .000 - Rp 1.500.000 sebesar 11\%, Untuk penghasilan Rp 1.500.000 - Rp 2.000.000 dan penghasilan lebih dari $\mathrm{Rp} 2.000 .000$ masih 0\%. Dari diagram 3B diketahui bahwa pendapatan pemandu wisata Nyarai beragam tergantung keaktifan dan intensitas mereka memandu. Rata-rata penghasilan di bawah Rp 500.000 adalah beberapa sampingan bagi masyarakat buruh tani dan pekerjaan bagi pemuda biasanya mengganggur di warung. Pemandu wisata yang loyal dan paling aktif justru adalah pemandu yang dulunya adalah para penebang pohon yang merasakan pendapatan dan profit ekonomi yang lebih baik ketika menjadi pemandu wisata daripada menebang pohon. Hal ini mengindikasikan bahwa ketertarikan masyarakat untuk terlibat sebagai pemandu wisata cukup besar sehingga dampak pendapatan sebagai pemandu cukup untuk memenuhi kebutuhan hidup untuk skala masyarakat perdesaan

Untuk Gambar 3C tingkat penghasilan Responden masyarakat ditambah dengan penghasilan menjadi pemandu, penghasilan masyarakat paling banyak adalah kisaran Rp 1.000.000 - Rp 1.500.000 dengan prosentase $37 \%$, urutan kedua kisaran Rp 1.000 .000 - Rp 1.500 .000 sebesar $31 \%$, urutan ketiga pendapatan lebih besar dari Rp 2.000 .000 sebesar $26 \%$, penghasilan lebih dari Rp $500.000-$ Rp 1.000 .000 sebesar $6 \%$, dan $0 \%$ untuk penghasilan dibawah Rp 500.000. Dari data ini terlihat adanya penambahan pendapatan masyarakat dari penghasilan sebelum menjadi pemandu ditambah dengan penghasilan dari jadi pemandu. Pendapatan masyarakat yang terlibat menjadi pemandu ratarata meningkat setelah menjalankan pekerjaan utama dan pekerjaan tambahan menjadi pemandu wisata. Pendapatan terbesar pada skala Rp 1.500.000- Rp 2.000.000. Hal ini mengindikasikan bahwa dengan keterlibatan masyarakat sebagai pemandu wisata, penghasilan setelah pemandu meningkat daripada penghasilan sebelum menjadi pemandu wisata. Besar kenaikan berbeda-beda karena hal ini tergantung tingkat keaktifan pemandu wisata. Pemandu yang paling aktif dan loyal adalah pemandu yang dulunya adalah penebang pohon, dengan meninggalkan aktifitas sebagai penebang pohon mereka beralih menjadi pemandu dengan keterlibatan yang cukup aktif dalam mendukung wisata dan mendapat profit ekonomi yang lebih besar daripada menjadi penebang pohon. Perubahan perilaku ekonomi masyarakat yang dulunya adalah penebang pohon perlahan sudah berubah dan bisa memilih sesuatu yang lebih baik dengan mendapatkan profit ekonomi yang lebih besar dengan menjadi pemandu dan alam hutan yang lebih terjaga dengan meninggalkan aktivitas penebangan.

Untuk Gambar 3D, prosentase masyarakat yang menjadi pemandu wisata Nyarai 95\% diantaranya menyatakan adanya kenaikan atau perubahan tingkat pendapatan dan $5 \%$ lainnya menyatakan tidak mengalami kenaikan pendapatan. Maka, dalam ini mengindikasikan bahwa manfaat dari kehadiran pariwisata Nyarai ini terhadap ekonomi terlihat adanya perubahan perilaku masyarakat lokal yang dari dulu bergantung kepada hutan dengan penebangan pohon, namun setelah adanya aktivitas ekonomi dari pariwisata ini dengan dibutuhkannya peran masyarakat sebagai pemandu maka sebagaian besar penebang pohon sudah beralih menjadi pemandu dan pengurus wisata Nyarai. Maka dalam hal ini telah terjadi perubahan perilaku ekonomi masyarakat lokal untuk menjadi lebih baik karena profit dari aktivitas ekonomi pariwisata yang cukup menguntungkan untuk masyarakat lokal

Perubahan perilaku ekonomi lainnya dalam aktivitas wisata ini adalah terbukanya kesempatan kerja. Untuk Kesempatan kerja yang ditawarkan memang belum begitu besar, tetapi untuk skala masyarakat pedesaan hal ini lebih baik daripada menjadi penebang pohon dengan penghasilan yang sangat kecil namun membutuhkan banyak tenaga ataupun pengangguran yang tidak ada penghasilan. Kesempatan kerja terbuka bagi penebang pohon yang beralih untuk terlibat ke sekor wisata seperti menjadi pemandu dan pengurus Pokdarwis, pemuda yang pengangguran, serta ibu-ibu Rumah Tangga. Pendapatan dari usaha lbu-lbu Rumah Tangga dengan berjualan dan membuka warung makan menjadikan tambahan pendapatan untuk keuangan keluarga 


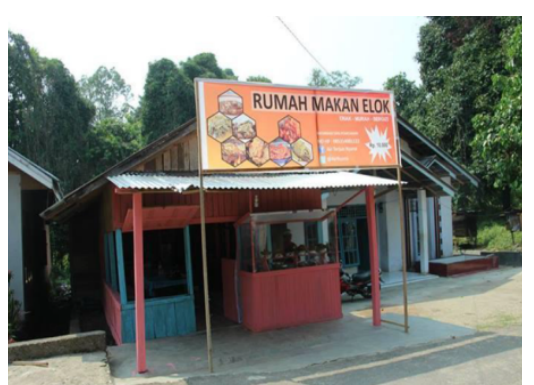

Sumber : Dokumentasi LA Adventure, 2014

(A)

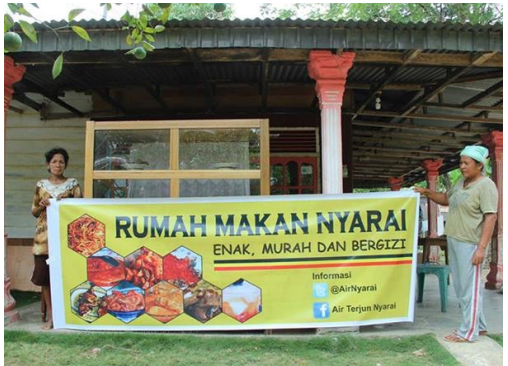

(B)

Gambar 4 : Rumah Makan Yang Buka Di Kawasan Nyarai

(A) Rumah Makan Elok Depan Gapura Nyarai

(B) Rumah Makan Nyarai Dekat Simpang Belek

Dengan adanya Pengembangan Ekonomi Lokal menjadi strategi dalam pemberdayaan masyarakat lokal, pemerintah lokal, serta industri-industri lokal. Dalam konteks pariwisata Air Terjun Nyarai dengan kehadiran pariwisata ini sudah mulai mewujudkan sasaran Pengembangan Ekonomi Lokal yaitu mengentaskan kemiskinan. Untuk sektor perbaikan infrastruktur saat ini belum begitu terlihat karena pengembangan wisata adalah swadaya masyarakat. Pemerintah saat ini baru membantu dalam kerjasama promosi dan motivator. Pemerintah juga mendukung penuh karena pengelolaan Nyarai dilakukan secara Bottom Up Planning berdasarkan inisiasi dari masyarakat. Secara ekonomi masyarakat sudah bisa dikatakan sejahtera karena aktivitas baru dan tambahan pendapatan.

\section{Analisis Pengaruh Pariwisata Nyarai terhadap Pemberdayaan Masyarakat Lokal}

Pemberdayaan masyarakat dalam pengelolaan Pariwisata Air Terjun Nyarai dimulai melalui terbentuknya Kelompok Sadar Wisata LA Adventure. Pokdarwis LA Adventure bukanlah karakter Pokdarwis yang berdiri dahulu baru mengembangkan wisata, Pokdarwis LA Adventure justru tercipta dari pariwisata Nyarai yang mulai berkembang. Pokdarwis LA Adventure terbentuk di inisiasi oleh Saudara Ritno Kurniawan dan kawan-kawan yang berjumlah lima orang yang menjelajah hutan dan mempublikasi keindahan Air Terjun Nyarai sehingga diketahui oleh banyak orang. Pokdarwis LA Adventure terbentuk karena kebutuhan pengelolaan dalam mengoptimalkan pengelolaan potensi sumber daya yang ada dalam pengembangan Wisata Air Terjun Nyarai.

Dalam pemberdayaan masyarakat dalam Pengembangan Pariwisata Air Terjun Nyarai melibatkan masyarakat lokal seutuhnya mulai dari perncanaan wisata sampai pelaksanaan dan evaluasi ketika Pariwisata Nyarai mulai ramai dan butuhnya suatu lembaga pengelola. Bentuk pemberdayaan masyarakat lokal Gamaran Korong Salibutan pada tangga partisipasi berada pada tingkatan tertinggi yaitu Degree Citizen Power (Tingkat Kekuasaan ada di masyarakat). Hal ini bisa terlihat dari kemampuan masyarakat lokal dalam membuka kemitraan (partnership) dengan berbagai pihak, Pelimpahan Kekuasaan (Delegated Power) dalam melaksanakan program pengembangan wisata, dan kemampuan masyarakat Pengendalian (Citizen Control) segala program pengembangan desa melalui monitoring dan evaluasi program pengembangan pariwisata Nyarai. Berikut Skala keterlibatan masyarakat lokal dalam Tangga Partisipasi masyarakat dalam pengelolaan wisata Air Terjun Nyarai:
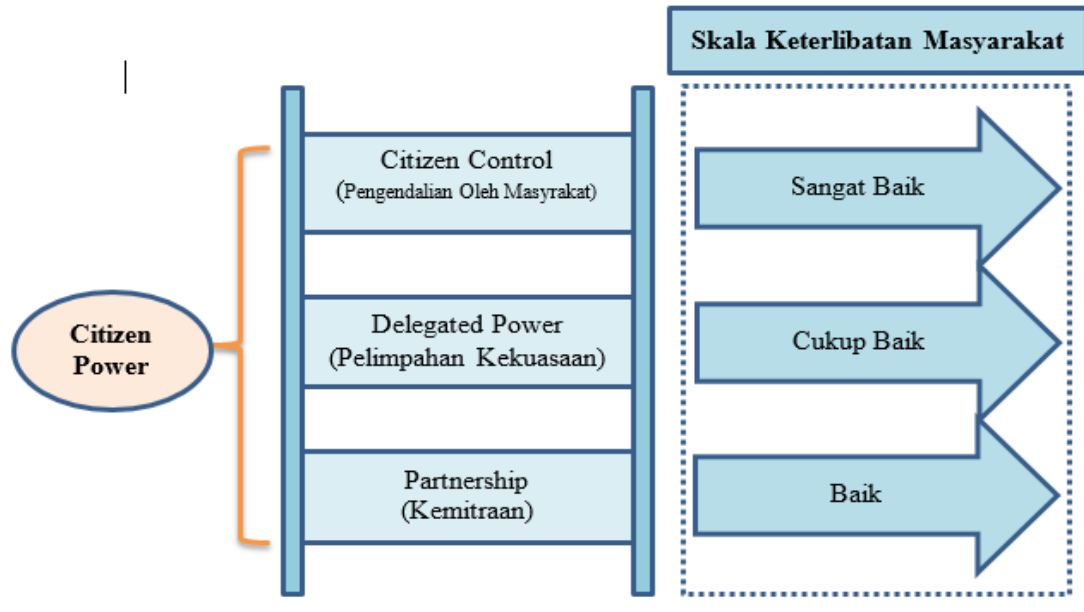

Sumber : Analisis Penulis, 2016 
Gambar 5 : Skala Tangga Partisipasi Masyarakat Dalam Pengelolaan Wisata Air Terjun Nyarai

Pemerintah juga berperan dalam pembinaan membangun partisipasi masyarakat lokal untuk terlibat dalam sektor pariwsata Nyarai. Pemerintah berusaha membangun dan menghimbau masyarakat lokal untuk aktif terlibat dan berpartisipasi dalam perencanaan, pengelolaan, sampai evaluasi. Keterlibatan pemerintah secara langsung tidak ada, tetapi lewat garis koordinasi dengan Pokdarwis LA Adventure Pemerintah menjadi fasilitator dalam membina masyarakat Korong Salibutan untuk terlibat optimal

\section{Analisis pengembangan pariwisata berbasis masyarakat dalam Pengembangan Pariwisata Air Terjun Nyarai yang melibatkan partisipasi dan pemberdayaan masyarakat dalam menunjang Pengembangan Ekonomi Lokal}

Pariwisata Air Terjun Nyarai bisa disebut sebagai Pariwisata Berbasis Masyarakat tentu tidak lepas dari bentuk keterlibatan masyarakat didalamnya. Keterlibatan masyarakat lokal beragam dan saling melengkapi dalam memberikan pelayanan penunjang wisata kepada wisatawan sebagai Tamu. Keterlibatan masyarakat sebagai Pengurus Pokdarwis tentu harus ada ilmu dan pembekalan kepada masyarakat sehingga mereka bisa paham peran mereka secara profesional sebagai pengurus pengelola wisata. Keterlibatan masyarakat dalam pengelolaan juga sangat optimal dimana $85 \%$ pengurus Pokdarwis adalah masyarakat lokal Gamaran Korong Salibutan

Pariwisata Berbasis Masyarakat dalam pengelolaan wisata Air Terjun Nyarai memiliki keterkaitan dengan Pengembangan Ekonomi Lokal. Pengembangan Ekonomi Lokal pada dasarnya memiliki dua kata kunci yaitu Kerjasama antar komponen dan pemanfaatan Sumber daya secara Optimal. Kerjasama antar komponen yang dimaksudkan adalah kerjasama antara semua pihak yang terlibat. Dalam kasus Pariwisata Air Terjun Nyarai kerjasama antara Pihak Pokdarwis LA Adventure yang merangkum masyarakat sudah memiliki garis koordinasi kerjasama dengan Pihak Pemerintah sebagai fasilitator yang memberikan ilmu dan pelatihan kepada masyarakat. Pengembangan Pariwisata Berbasis masyarakat memberikan dampak kepada masyarakat berupa pemberdayaan masyarakat itu sendiri. Masyarakat menjadi berdaya dan tahu apa yang harus dilakukan dalam melihat peluang potensi wisata yang ada dalam Hutan Gamaran. 


\section{Analisis Peran Pemangku Kepentingan yang terkait dalam pengelolaan dan pengembangan lokal Wisata Air Terjun Nyarai}

Pemerintah memiliki andil dan peran dalam mendukung pariwisata dan membina masyarakat lokal. Dalam Penyusunan Dokumen Pengembangan Pariwisata Daerah, Pengembangan Wisata Air Terjun Nyarai sudah masuk dalam RIPPDA Kabupaten Padang Pariaman tahun 2013-2023 dalam Pengembangan Batang Anai-Lubuk Alung sebagai Kawasan Pintu Gerbang Sumatera Barat, Rekreasi Alam dan Water-front Resort berupa Pengembangan Adventure Tourism dan Rekreasi Wisata Alam Pegunungan Lubuk Alung dan Sekitarnya. Dukungan Pemerintah dalam Pembangunan Pariwisata saat ini untuk bantuan dana belum bisa, tetapi pemerintah tetap berupaya mencarikan dana untuk pembangunan fisik. Sementara dukungan pemerintah baru sebatas Program pembinaan masyarakat dimana pemerintah sebagai fasilitator dalam pemberdayaan masyarakat terkait apa yang mereka butuhkan dalam pengembangan

Peran Pokdarwis LA Adventure adalah mewadahi semua ide-ide dari pengurus dan masyarakat yang terlibat mulai dari perencanaan, pelaksanaan pengembangan sampai evaluasi kekurangan. Pokdarwis disini berperan juga dalam menjalin kerjasama dan kemitraan dengan berbagai pihak, baik dengan pemerintah daerah sebagai fasilitator maupun lembaga lain seperti NGO ataupun komunitas lainnya.

Masyarakat sebagai Tuan Rumah memiliki peranan penting. Masyarakat harus belajar memahami perannya dalam pariwisata Air Terjun Nyarai. Sebagai Tuan Rumah maka masyarakat harus menjaga nama baik dari kawasan Nyarai itu sendiri. Peran masyarakat yaitu ada yang berperan dalam kepengurusan Pokdarwis dengan berbagai devisi seperti keamanan, promosi, bendahara dan sebagainya. Peran lain adalah pemandu wisata yang menjadi penanggung jawab saat melakukan trekking. Selain itu masyarakat juga merasakan dampak dari wisata ini dan mendukung wisata menajdi penjual makanan di beberapa titik wisata Nyarai

Wisatawan juga berperan sebagai tamu dan penyumbang pemasukan operasional aktivitas wisata. Dengan banyaknya wisatawan yang memiliki minat untuk datang ke Nyarai, wisatawan adalah salah satu stakeholder yang penting dalam keberlangsungan pariwisata Nyarai. Tanpa adanya wisatawan, tentu pariwisata ini tidak akan berkembang karena aliran dana operasional pengelolaan berasal dari uang kontribusi wisatawan.

Untuk keberlangsungan Pariwisata Air Terjun Nyarai sebagai salah satu wisata Minat Khusus dan Pariwisata Outdor, pengelola wisata melalui Pokdarwis LA Adventure juga menjalin kemitraan dengan beberapa pihak ketiga yang memiliki ketertarikan akan potensi wisata dalam Hutan Gamaran yang bisa dijadikan wisata alam konservasi serta Ecotourism. Beberapa pihak yang memiliki kepentingan sama tersebut seperti National Geograhic dan Cerdas Lingkungan Indonesia.

\section{Kesimpulan}

Dari hasil analisis penelitian yang dilakukan telah menjawab pertanyaan penelitian tersebut berupa bagaimana perubahan perilaku ekonomi masyarakat dalam mendukung pariwisata Nyarai serta pengaruh pariwisata Nyarai terhadap pemberdayaan masyarakat lokal. Kehadiran Pariwisata Air Terjun Nyarai telah membuat terjadinya perubahan perilaku ekonomi masyarakat lokal berupa aktivitas ekonomi masyarakat yang meninggalkan aktivitas penebangan dan berpaling ke kegiatan pariwisata dan munculnya aktivitas ekonomi baru. Dalam hal ini terjadi peningkatan pendapatan untuk masyarakat yang menjadi pengelola dan pemandu wisata serta kesempatan kerja dengan adanya usaha rumah makan dan warung kecil.

Pengaruh Pariwisata secara ekonomi dengan adanya perubahan perilaku masyarakat ini sesuai dengan Teori [6] bahwa Pariwisata memberi kontribusi kepada penciptaan lapangan pekerjaan, perbaikan infrastruktur dan membantu perkembangan infrastruktur wilayah. Dalam kasus Pariwisata Air Terjun Nyarai kesempatan kerja yang ditawarkan memang belum begitu besar, tetapi untuk skala masyarakat pedesaan hal ini sudah lebih baik daripada menjadi pekerja keras sebagai penebang pohon dengan penghasilan yang tidak begitu besar pengangguran yang tidak ada penghasilan. Kesempatan kerja terbuka bagi masyarakat yang beralih dari penebang pohon menjadi pelaku wisata serta pemuda-pemudi yang pengangguran dan ibu-ibu Rumah Tangga masyarakat lokal Gamaran Korong Salibutan. Salah satu tujuan dari Kepariwisataan (Pasal 4 Undang-Undang No 10 Tahun 2009 tentang Kepariwisataan) bahwa Pariwisata berdampak terhadap ekonomi yaitu: meningkatkan pertumbuhan ekonomi, meningkatkan kesejateraan rakyat, menghapus kemiskinan, dan mengatasi pengangguran. Dalam hal ini telah terjadi perubahan perilaku ekonomi masyarakat dalam mendukung pengembangan Pariwisata Air Terjun Nyarai. 
Dampak perubahan perilaku ekonomi terhadap pembangunan skala Kabupaten Padang Pariaman belum terlalu terlihat. Perbaikan infrastruktur wilayah untuk aksesibilitas wisata belum dilakukan oleh pemerintah daerah, Pemerintah belum memberikan bantuan fisik seperti infrastrtruktur penunjang wisata.

Kehadiran Pariwisata mampu mendorong masyarakat untuk berpartisipasi secara aktif dalam rangka mencapai tujuan kesejahteraan dan pemberdayaan masyarakat lokal [1]. Dalam kasus kehadiran Air Terjun Nyarai sebagai sebuah potensi wisata alam menunutut adanya peran serta dari masyarakat ketika wisata ini berkembang. Pemberdayaan masyarakat dalam pengelolaan Pariwisata Air Terjun Nyarai dimulai melalui terbentuknya Kelompok Sadar Wisata LA Adventure yang mengajak dan memberdayakan masyarakat. Bentuk pemberdayaan masyarakat lokal Gamaran Korong Salibutan seperti teori tangga partisipasi menurut [5] berada pada tingkatan tertinggi yaitu Degree Citizen Power (Tingkat Kekuasaan ada di masyarakat). Hal ini bisa terlihat dari kemampuan masyarakat lokal dalam membuka kemitraan (partnership) dengan berbagai pihak, pelimpahan kekuasaan (delegated power) dalam melaksanakan program pengembangan wisata, dan kemampuan pengendalian masyarakat (citizen control) segala program pengembangan desa melalui monitoring dan evaluasi. Jadi tangga partisipasi masyarakat dalam pariwisata Air Terjun Nyarai adalah tingkatan tertinggi dari teori [5] karena pariwisata Air Terjun Nyarai murni berkembang secara Bottom Up Planning dari masyarakat lokal.

\section{Daftar pustaka}

[1] Hadiwijoyo, Suryo Sakti. Perencanaan Pariwisata Pedesaan Berbasis Masyarakat (Sebuah Pendekatan Konsep). Graha IImu : Yogyakarta. 2012.

[2] Pedrana, Margherita. Local Economic Development Policies and Tourism. An Approach to Sustainability and Culture. Regional Science Inquiry Journal Volume V (1) 2013. European University of Rome. 2013.

[3] Peraturan Menteri Kehutanan No 89 tahun 2014 tentang Hutan Desa. 2014.

[4] Purnomo, Cahya. Marketing Strategy of Special Interest Tourism Product of Cave Cerme, Imogiri, Bantul. Jurnal Karisma Vol 3(2) : 99-112, 2009

[5] R. Arnstein, Sherry. A Ladder of Citizen Participation. JAIP, Vol. 35, No. 4, July 1969, pp. 216-224. 1969.

[6] Ratih Sari, Suzanna. Peran Pariwisata Dalam Pembangunan. Semarang : Badan Penerbit Universitas Diponegoro Semarang. 2003.

[7] Suharto,Edi. Membangun Masyarakat Membangun Rakyat. Kajian Strategis Pembangunan Sosial dan Pekerja Sosial. Bandung : Rafika Aditama. 2006.

[8] Theerapappisit, Polladach. "The Bottom-Up Approach of Community-Based Ethnic Tourism: A Case Study in Chiang Rai. School of Social Sciences and Psychology, University of Western Sydney Australia," Intech Journal Strategies for Tourism Industry - Micro and Macro Perspectives Published in print edition April, 2012

[9] Wardiyanta. Metode Penelitian Pariwisata. Yogyakata : Andi Yogyakarta. 2006. 